\title{
REFUGIADOS EM QUADRINHOS: PROPOSTA DE ENSINO DE GEOGRAFIA NOS CURSOS INTEGRADOS DO IFSP - CAMPUS AVARÉ/SP
}

\author{
Refugees in comics: geography teaching proposal in the integrated courses of IFSP - \\ Campus Avaré / SP
}
Refugiados en cómics: propuesta de enseñanza de geografía en lo bachillerato del IFSP - Campus Avaré / SP

\author{
Juliano Ricciardi Floriano Silva ${ }^{1}$ \\ Diânice Oriane da Silva ${ }^{2}$
}

Recebido em 04/2017 - Aceito em 07/2017.

\begin{abstract}
Resumo
Este artigo é resultado de um projeto de ações de ensino, na modalidade de monitoria, realizada no Campus do IFSP, na cidade de Avaré, estado de São Paulo. O intuito desse projeto foi desenvolver com os alunos do ensino técnico integrado ao ensino médio, uma proposta de emprego da arte sequencial das histórias em quadrinhos na disciplina de Geografia. A arte sequencial é utilizada desde o entretenimento infanto-juvenil na forma das HQs como também é uma técnica adotada no cinema, na forma de storyboards, usada no planejamento de cenas que serão rodadas em cenários distintos. Acredita-se que essa linguagem pode ser utilizada também, com finalidades didáticopedagógicas, por isso, foram adaptados relatos de refugiados, que no momento de sua aplicação recheavam os noticiários internacionais, mostrando o drama dessas pessoas que se deslocavam em busca de uma vida melhor. Após a introdução e sensibilização ao tema, realizado pelo docente e o auxílio do bolsista/monitor, os alunos pesquisaram outros relatos de refugiados e transformaram em histórias em quadrinhos, que podem ser consultados na rede mundial de computadores.
\end{abstract}

Palavras-Chave: Histórias em Quadrinhos; Refugiados; Ensino de Geografia.

\begin{abstract}
This article is the result of a teaching-action Project at the TA (teaching assistant) mode, held at the Campus of IFSP, in the city of Avaré, state of São Paulo. The aim of this project was to develop a proposal for the use of the sequential art of comics in the subject of Geography with the students of vocational education integrated to high school. The sequential art is used since the infantile-juvenile entertainment in the form of comics and is a technique also adopted in the cinema, in the form of storyboards, used in the planning of scenes that would be shot in different scenarios. It is believed that this language can also be used for didactic-pedagogical purposes, therefore, refugee reports, which were fillingup the international News during the Project implementation, were adapted, showing the drama of these people who were moving in the search for a better life. After introducing and sensitizing the students to the theme, conducted by the teacher and the support of the TA, they researched other reports of refugees and turned them into comic books, which can be seen on the worldwide web.
\end{abstract}

Keywords: Comics; Refugees; Geography teaching.

\section{Resumen}

Este artículo es resultado de un proyecto de acciones de enseñanza, en la modalidad de monitoria, realizada en un Campus del IFSP, en la ciudad de Avaré, estado de São Paulo. El intuito de este proyecto fue desarrollar con los alumnos de la enseñanza técnica junto al bachillerato, una propuesta de empleo del arte secuencial de los cómics en la asignatura de Geografía. El arte secuencial es utilizado en el entretenimiento infanto-juvenil por medio de los cómics, así como también es una técnica adoptada en el cine, en la forma de storyboards, usada en el planeamiento de escenas que 
serán proyectadas en escenarios distintos. Se cree que ese lenguaje puede ser utilizado también, con finalidades didáctico - pedagógicos, por eso, fueron adaptados relatos de refugiados, que en el momento de su aplicación rellenaban los noticieros internacionales, mostrando el drama de estas personas que se desplazaban en una búsqueda por una vida mejor. Después de la introducción y sensibilización al tema, realizado por el docente y la ayuda del becario/ monitor, los alumnos investigaron otros relatos de refugiados y los transformaron en cómics, que pueden ser consultados en la red mundial de computadoras.

Palabras - Clave: Historias en cómics; Refugiados; Enseñanza de Geografía.

Recebido em 04/2017. Aceito em 07/2017

\section{INTRODUÇÃO}

As histórias em quadrinhos são tanto veículos transmissores de informação como de lazer para grande parte da população que faz uso dessa forma de leitura. Pode-se afirmar que as histórias em quadrinhos surgiram em pequenas publicações em tiras de jornais, que, em pouco tempo, conquistaram um adepto grupo de leitores, os quais, por sua vez, foram os responsáveis por estimular as histórias em quadrinhos a se separarem dos jornais e caminharem com as próprias pernas.

A impressionante massa de leitores de história em quadrinhos é um dos pontos que chama a atenção para compreender como um tipo de linguagem tão simples se tornou célebre e como seria possível relacioná-la com a educação dos jovens. Portanto, o objetivo geral deste trabalho foi buscar respaldo científico para a aplicação das histórias em quadrinhos no ensino de Geografia, enfatizando o tema migrações. Serão apresentados, um breve levantamento bibliográfico sobre as histórias em quadrinhos como também no que tange a temática dos migrantes, classificados como refugiados e as respectivas metodologias e resultados obtidos.

\section{AS HISTÓRIAS EM QUADRINHOS}

Consideradas como um veículo de expressão criativa, no qual as artes visuais e as letras estão unidas com a função de narrar uma história, as histórias em quadrinhos podem ser publicadas inteiras, em revistas e livros, ou em capítulos publicados periodicamente por jornais, ou em revistas, na forma de tiras. Elas podem contar qualquer tipo de história, seja para adultos ou crianças, sendo as mais comuns as de aventuras e as cômicas, que se firmaram em uma posição inegável na cultura popular.

Segundo Moya (1980) no passado, o grande público dos quadrinhos começou a perturbar algumas organizações sociais, religiosas, políticas e educacionais, que consideravam esse tipo de publicação subversiva, nociva às crianças e fonte de grande parte dos problemas enfrentados pela sociedade. 
Entretanto, dada à fragilidade nas representações mentais da criança, bem como sua pouca experiência de vida, esta é levada a se desinteressar pela leitura de livros tradicionais, o que nas HQs por meio das gravuras, conduz a criança, a ter uma facilidade de compreensão, fazendo com que ela desenvolva o interesse pela leitura e, à medida que vai amadurecendo sua inteligência, haverá uma tendência natural a buscar livros cada vez mais sérios, que atenderá às diferentes fases do desenvolvimento infantil.

Eisner (1989) defende que, diferentemente da leitura textual, os quadrinhos são um tipo de leitura que também necessita de interpretação do leitor.

Durante os últimos cem anos, o tema da leitura tem sido diretamente vinculado ao conceito de alfabetização; [...] aprender a ler[...]tem significado aprender a ler palavras[...] Mas[...] gradualmente a leitura foi se tornando objeto de um exame mais detalhado. Pesquisas recentes mostram que a leitura de palavras é apenas um subconjunto de uma atividade humana mais geral que inclui a decodificação de símbolos, a integração e a organização de informações[...]Na verdade, pode-se pensar na leitura no sentido mais geral como forma de atividade de percepção. A leitura de palavras é uma manifestação dessa atividade; mas existem muitas outras leituras de figuras, mapas, diagramas, circuitos, notas musicais... (EISNER, 1989 , p. 8)

Essa interpretação ocorre no momento em que o leitor necessita fazer uma interpretação visual das gravuras. Moya (1980) relata que

Os quadrinhos são um conjunto e uma sequência [...] a ação contínua estabelece a ligação entre diferentes figuras. Existem cortes de tempo e espaço mas estão ligados a uma rede de ações lógicas e coerentes. (MOYA, 1980, p. 33).

Segundo Cagnin apud Anselmo (1975), essa forma narrativa por imagens fixas pode transportar várias idéias por meio das representações no texto, sejam elas visuais ou verbais, ambas desenhadas em contraposição ao fundo. Adaptando essa interpretação sequencial de fatos e observando a imagem abaixo (Figura 1), podemos diferenciar os quadrinhos em dois blocos :

1ํ bloco: Reprsentação analógica, é a representação dos seres (pessoas, animais ou objetos) que entram na ação narrativa (1).

2o bloco: Ações convencionais, típicas dos quadrinhos, como o movimento do personagem (2 A), os sons (2 B), caracterizados por onomatopéias, que são compreendidas em todas as línguas, excetuando os balões e legendas (2 C) que destacam a língua nativa do leitor. 
Além dessa interpretação visual, há também representação dos balões de diálogo, que podem ter vários formatos, dependendo da necessidade da cena ou da fala do personagem (Figura 2).

Figura 1 - Blocos de diferenciação de ações que podem ser percebidos em uma publicação de arte sequencial.

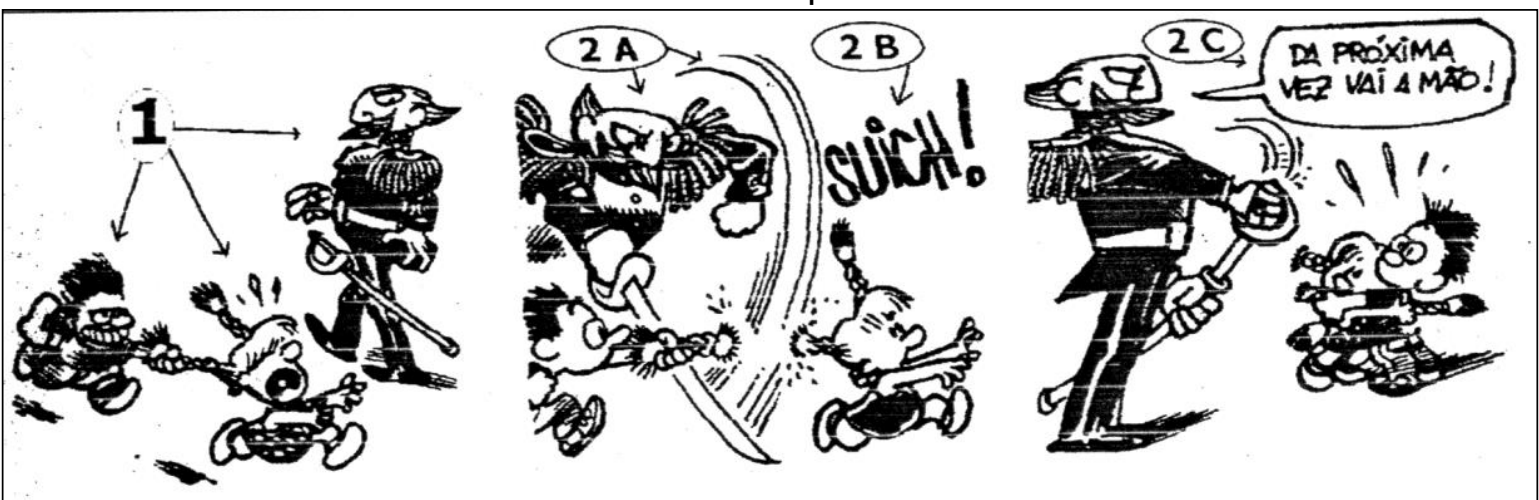

Fonte: Coutinho (1993, p. 12), adaptado pelos autores (2017).

Figura 2 - Tipos de balões de diálogos (da esq. para a dir.), diálogo comum, pensamento, grito/discussão.

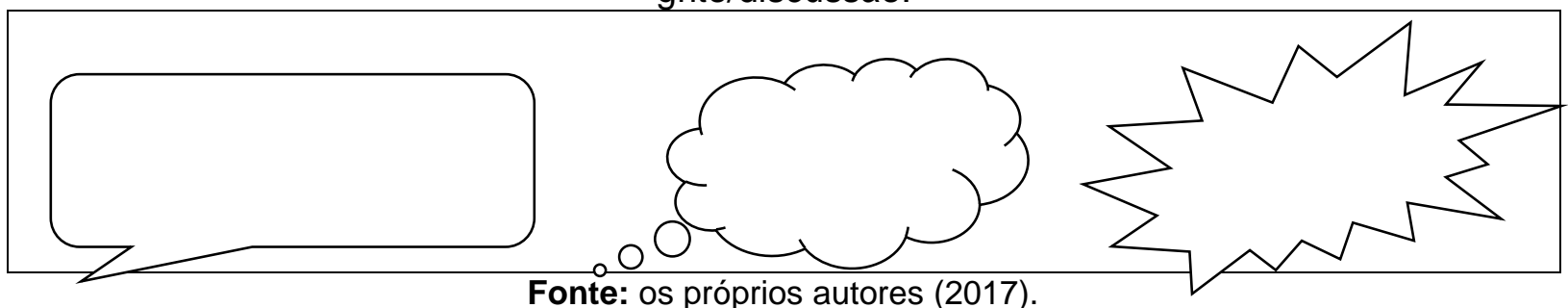

Fonte: os próprios autores (2017).

A proposta de inserir as histórias em quadrinhos na sala de aula é para diminuir a distância entre o visual e a palavra escrita. Com o mesmo intuito, encontram-se muitas experiências que foram usadas com sucesso na disseminação de ideias, como campanhas de prevenção de acidentes no trânsito, vacinação e cuidados com a higiene, representadas por meio da arte sequencial. Assim, esperamos que essa ferramenta baseada nos quadrinhos atuecomo um verdadeiro diálogo entre o transmissor e o receptor das informações, principalmente quando o público é formado por jovens que ainda não desenvolveram o hábito pela leitura.

Assim, esse tipo de linguagem que une a ilustração e a prosa, pode servir de apoio para transformar aprendizagem do conhecimento geográfico mais atraente para os alunos. 


\section{A ABORDAGEM DO TEMA: REFUGIADOS}

O tema que foi elencado para o trabalho em sala de aula, relacionava-se com as migrações que consta no Plano Pedagógico de Curso (PPC), dos primeiros anos dos três cursos Técnicos Integrados ao Ensino Médio de Agroindústria, Lazer e Mecatrônica.

Após todo o trabalho com o apoio de textos, livro didático e uso de imagens e vídeos curtos sobre a temática, focamos em uma modalidade de fluxo migratório que estava inclusive em destaque no segundo semestre de 2015, que era (e ainda é) o drama dos refugiados que partem da África e da Ásia em direção aos países europeus.

Esses grupos, pressionados por questões religiosas, étnicas e principalmente políticas, originam-se de países como a Síria, Iraque, Líbia, Afeganistão e Eritréia.

Não tendo apoio em seus países de origem, esses indivíduos se lançam a migrar a pé, quando possível por terra, para alcançar os países da Europa Central e Ocidental, ou então por meio de embarcações precárias que tentam atravessar o Mar Mediterrâneo, alcançando o continente tão esperado, muitas vezes, apenas seus cadáveres.

Crépeau (2006) entende como refugiados, o grupo de pessoas que no país de origem sentiram-se ameaçados ou de fato foram violados seus direitos, onde o Estado foi incapaz de proteger os direitos humanos de seus nacionais, o que os levou a fugir para escapar da situação de violência. Portanto, esse grupo emerge como consequência das ações ou omissões políticas empreendidas pelo Estado.

Segundo Moreira (2012)

Os refugiados são considerados migrantes que merecem proteção internacional, por terem sido forçados a se deslocar em função das situações de violência vivenciadas em seus países de origem. A necessidade não apenas de proteção, mas também de assistência é entendida como emergencial, diante da crise humanitária enfrentada internamente. Embora tidos como reais merecedores de proteção, existem limites colocados à admissão, materializados em critérios de seleção, bem como ao tempo de permanência nos territórios do Estado receptor. A categoria de refugiado carrega em si, portanto, as noções de transitoriedade, provisoriedade e temporalidade. Os refugiados se situam no limiar entre o país de origem e o país de destino. Ao transitar entre os dois universos, ocupam posição liminar, tanto em termos identitários, culturais e sociais, assentada na falta de pertencimento enquanto membros da comunidade receptora e nos vínculos introjetados por códigos partilhados com a comunidade de origem; quanto em termos jurídicos, ao deixar de exercitar, ao menos em caráter temporário, o status de cidadão no país de origem e portar o status de refugiado no país receptor (MOREIRA, 2012, p. 22).

Historicamente, durante a Segunda Guerra Mundial (1939-1945), temos uma referência à migração de etnias perseguidas pelo Nazi-Fascismo, especialmente os judeus. Entretanto, em todos os continentes, há questões de diversas ordens que acabam levando indivíduos abandonarem seus países de origem, para buscarem abrigo em terras distantes. 
Entendia-se que o caráter desse refúgio seria temporário; todavia, a imposição de governos ditatoriais ou então os conflitos internos nos países de origem, podem durar décadas, o que para o refugiado torna-se difícil crer em um possível retorno, tanto que alguns destes acabam constituindo família no país que o abrigou.

O acolhimento de refugiados, de acordo com Moreira (2012), tem como propósito também de utilizá-los como arma política visando deslegitimar o país de origem, ao rotulá-lo como perseguidor, repressor ou violador de direitos humanos. Como exemplo, pode-se citar a recepção que os Estados Unidos faziam aos cubanos, quando fugiam da repressão encabeçada por Fidel Castro, logo após a Revolução Cubana de 1959.

Entretanto, além de serem refugiados em uma pátria diferente da sua, acrescenta-se que sua receptividade não é bem vista pelos nacionais, especialmente, quando esse fluxo torna-se frequentes e grandes contingentes.

Atualmente, pode-se verificar que em determinados países da Europa, os refugiados serviram de apelo eleitoral para os partidos de extrema direita, como no caso da França, com a candidata a presidência Marine Le Pen, contraditória a política de apoio de refugiados da União Europeia ou mesmo da campanha encabeçada por Nigel Farage, que obteve êxito com o plebiscito que resultou na saída da Grã-Bretanha da União Europeia (BRexit) e que teve como estopim a política para refugiados do bloco.

\section{METODOLOGIA}

Para desenvolver esse projeto de ações de ensino, houve a necessidade submeter à avaliação da comissão interna do campus, pois haveria a necessidade de um aluno bolsista para o auxílio no desenvolvimento da proposta.

Enquadrado na modalidade de monitoria, houve uma seleção entre os alunos que se candidataram, exigindo apenas que estes tivessem habilidades artísticas manuais para o desenho, na forma de cartunismo o que além da minha experiência no assunto, contei com o auxílio da professora de Arte do campus que contribuiu muito para a seleção do bolsista.

Definido o bolsista/monitor, passamos a conversar em encontros semanais para troca de ideias e a definição de roteiros que foram propostos no trabalho.

Em busca de relatos de refugiados, buscamos na rede mundial de computadores, acesso a fontes fiéis que relatassem seu processo de deslocamento até o destino almejado. Entre as fontes mais confiáveis, optamos por um relato que foi obtido no site da ACNUR (Alto Comissariado das Nações Unidas para Refugiados).

Esse relato tratava do drama vivido por um jovem de um vilarejo rural de Honduras que sofria perseguição social por sua orientação sexual e que após uma difícil trajetória conseguiu refúgio no México (Figura 3). 
Além da história anterior, buscamos em um relato mais profundo, publicado na obra de Ismael Beah, intitulada Muito Longe de Casa: Memórias de um menino soldado, que retrata a difícil infância e adolescência do autor em Serra Leoa, quando foi recrutado por guerrilheiros para servirem um exército de resistência contra o governo do país (Figura 4).

Com a sensibilização proposta pelos dois relatos acima transformados em quadrinhos pelo bolsista/monitor, trabalhamos nas aulas seguintes com a noção de refúgio de acordo com a declaração universal dos direitos do homem confrontando com imagens e reportagens audiovisuais sobre o flagelo dos refugiados que partem da África e Ásia em direção a Europa.

Figura 3 - História de Antônio, um hondurenho que se refugiou no México, adaptado para Histórias em Quadrinhos, para sensibilização em sala de aula.

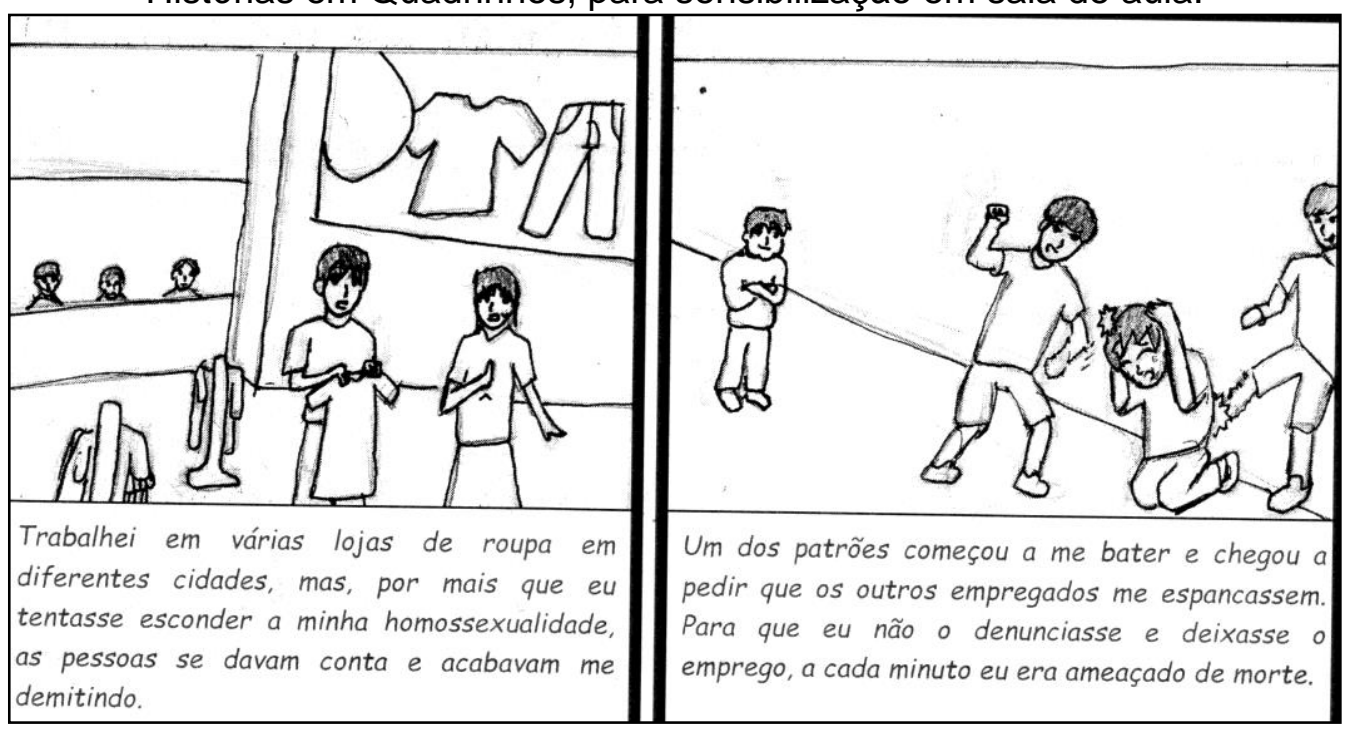

Fonte: Agência da ONU para Refugiados - ACNUR (2011).

Figura 4 - Relato de Ismael Beah, adaptada em quadrinhos para sensibilização dos alunos com o tema refugiados.

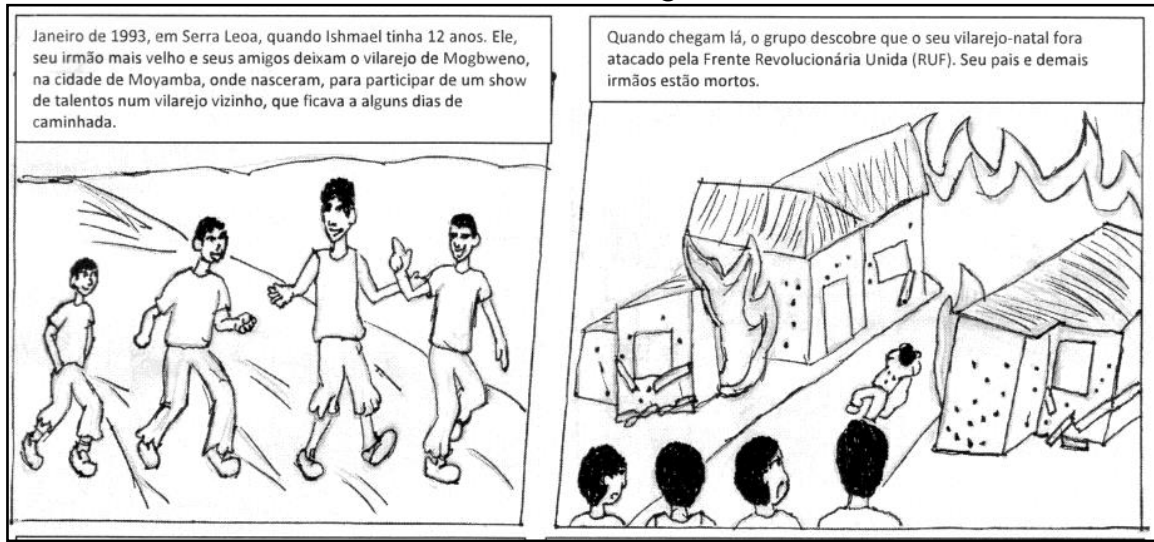

Fonte: Beah (2014). 
Após os debates em sala com os alunos, foi definida como atividade avaliativa, a produção das suas próprias histórias em quadrinhos que abordassem a mesma temática. Em duplas, os alunos buscaram outros relatos de refugiados na internet para criar a sua sequência de quadrinhos.

Com o intuito de evitar exageros e uma melhor adequação das histórias ou relatos de refugiados, solicitamos que os alunos entregassem na forma manual uma proposta de storyboard, do que se esperava retratar com o texto em anexo para análise do docente e do bolsista.

Para a produção dos quadrinhos, foi utilizado o software Pixton, disponível gratuitamente na internet que facilitaria para os alunos a tarefa de desenhar os personagens e o background dos quadros (Figura 5).

Figura 5 - Aluno desenhando sua sequência de quadros com o software Pixton, no laboratório de informática do campus (à dir.) e um dos quadros desenhados por ele, relatando o drama de um refugiado (à esq.).
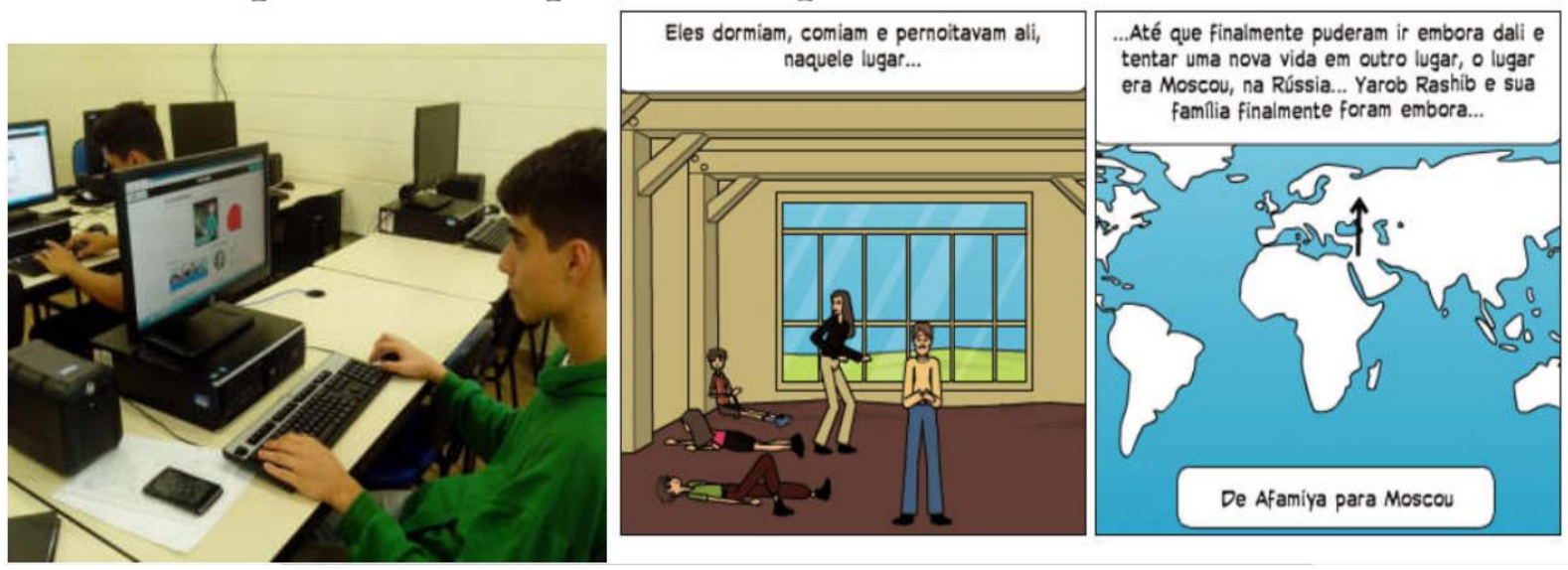

Fontes: os próprios autores (2015) e Pixton Comics Inc. (2017)

Para auxiliar no processo de utilização deste, o bolsista/monitor, encarregou-se de orientar em oficinas as instruções necessárias para a elaboração das HQs, o que ocorreu concomitante ao período de entrega das storyboards. Havendo a adesão total dos alunos, todos se propuseram a desenvolver tal atividade, inclusive houve relatos repetidos de refugiados, porém na produção das HQs, percebeu-se que a forma de interpretar o relato foi diferente, não só no desenho como também no destaque que cada aluno observou e enfatizou com sua $\mathrm{HQ}$.

\section{RESULTADOS}

A produção das HQs pelos alunos foi de extrema valia, pois ao mesmo tempo em que eles se dedicaram em imaginar os quadros que viriam retratar cada passagem do relato, estavam criando as fisionomias dos personagens e as ações que envolviam no plano 
de fundo da cena (backgound), tendo sempre em vista a atenção que o leitor deveria ter para a compreensão do que a HQ abordava.

Acrescenta-se também que as histórias apresentaram em sua maioria, uma sequência lógica dos fatos, o quem demonstra o empenho dos alunos em traduzirem o texto escrito para uma modalidade similar às antigas fotonovelas.

Nos relatos de refugiados que foram levantados pelos alunos, houve histórias que se repetiram, porém isso não foi um problema, pois a produção final dos quadrinhos foi distinta, não sendo detectadas cópias. Assim, dos 42 trabalhos recebidos, tiveram como base 0 relato de 27 refugiados que tinham suas origens, representados no gráfico abaixo:

Gráfico 1: Origem dos Refugiados, segundo levantado com a pesquisa dos alunos

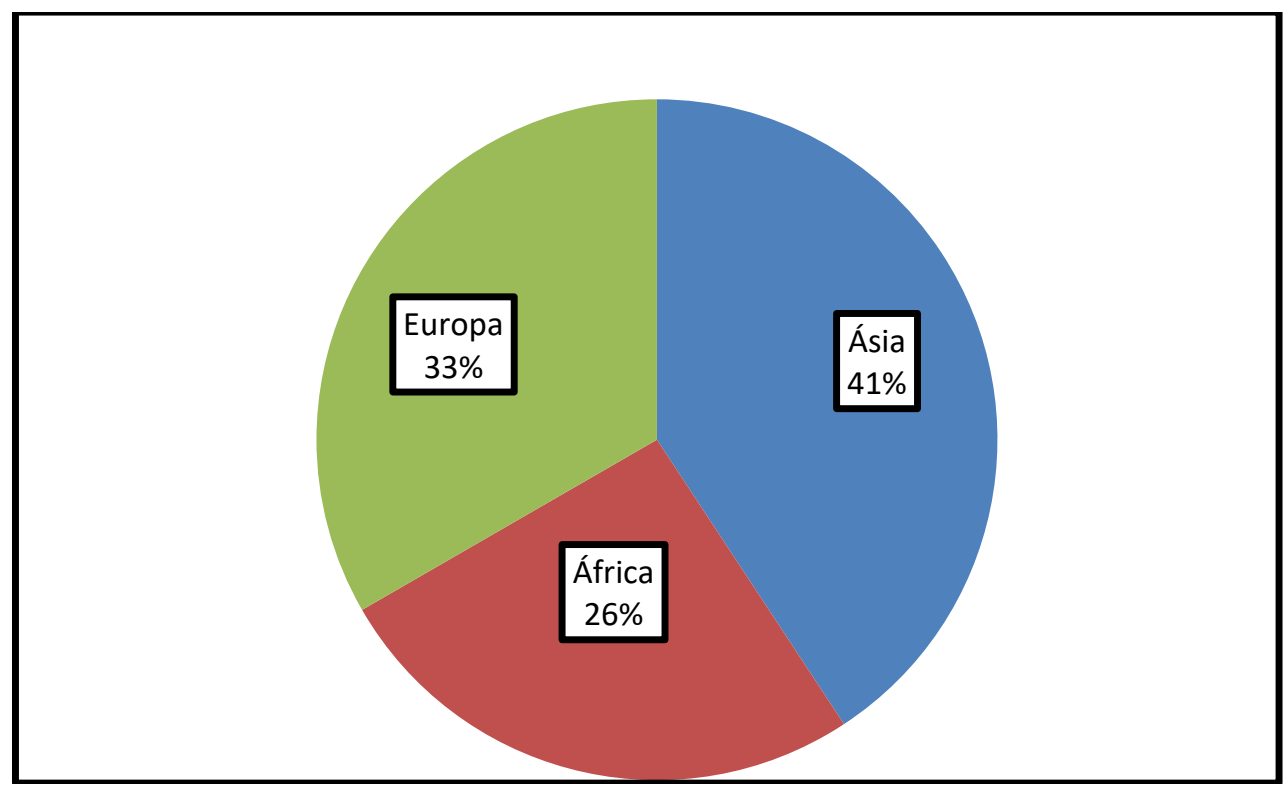

Fonte: os próprios autores (2015).

Entre os relatos mais encontrados na rede mundial de computadores, o continente asiático foi o que se destacou com $41 \%$ dos relatos (11 trabalhos). Apenas um trabalho abordava a fuga de um perseguido pelo regime do Taliban no Afeganistão, enquanto que os outros trabalhos referiam-se às famílias sírias que se deslocam do país desde 2011, quando começaram os ataques dos rebeldes para derrubar o governo do ditador Assad, aproveitando da onda democrática iniciada na Tunísia e se propagou pelo Norte da África e Oriente Médio, denominada de "Primavera Árabe".

$\mathrm{Na}$ Europa, os $33 \%$ dos relatos (nove trabalhos), enfatizavam a fuga dos judeus durante o regime nazista alemão entre as décadas 1930 e 1940. São relatos ricos em detalhes, referente à época da Segunda Guerra Mundial. 
Os outros $26 \%$ dos relatos (sete trabalhos), envolviam o continente africano, sendo três focando no conflito em Ruanda (1994) que resultou no genocídio de quase um milhão pessoas da etnia Tutsi, outros três focando na guerrilha da Guiné Equatorial e apenas um trabalho citando um refugiado que fugiu do Senegal, refugiando-se na Argentina.

Abaixo (Figura 6) o relato de uma família síria que se refugiou no Brasil, elaborado pelo aluno Guilherme Souza Caetano.

Figura 6 - Trecho inicial da sequência de quadrinhos, criado pelo aluno G. S. Caetano (10 ano de Mecatrônica), relatando o drama vivido pela família do sírio Mohamed que se refugiaram no Brasil.

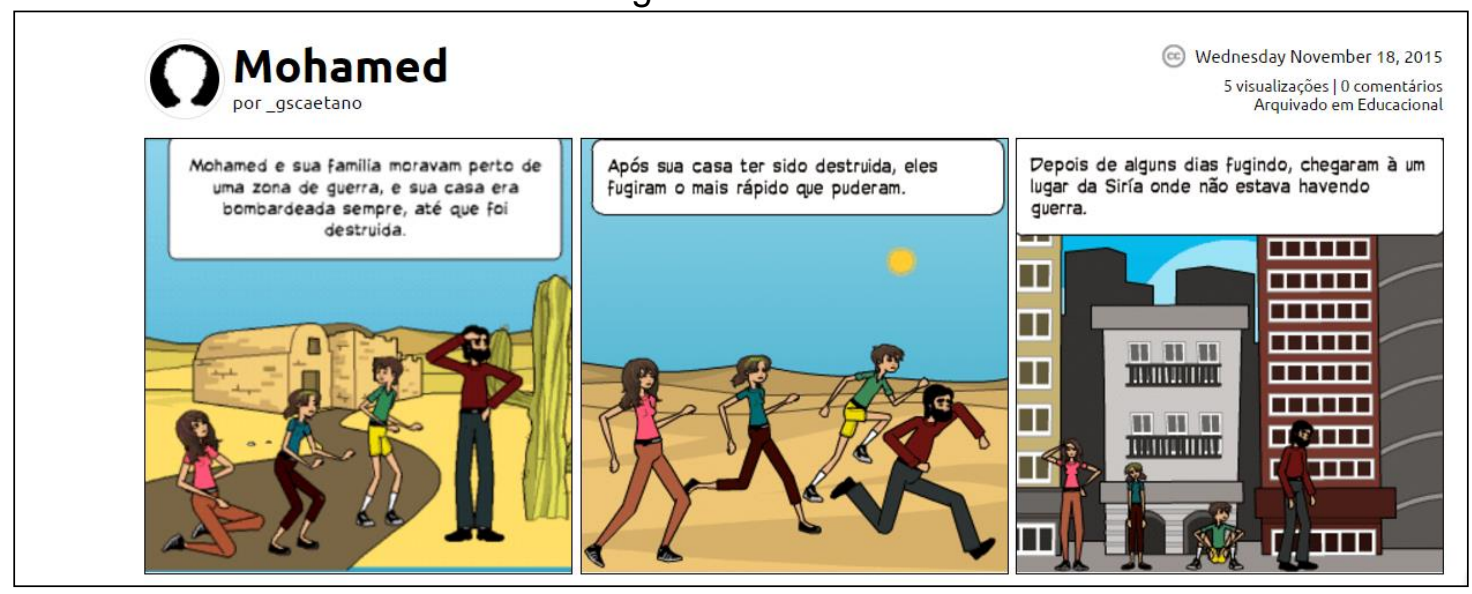

Fonte: Caetano (2015) e Pixton Comics Inc. (2017).

Com relação à aprendizagem, após toda a sensibilização realizada no início do trabalho, constatou-se que o tema migrações e especialmente no tocante aos refugiados, estava muito claro na mente deles e inclusive houve momentos que os alunos durante as aulas relatassem que haviam visto na televisão ou na internet o drama dos africanos em balsas tentando cruzar o mediterrâneo, além de explicarem para seus pais o porquê de tamanho êxodo em direção a Europa.

Portanto, além desse trabalho que envolveu a arte e a linguagem escrita, acrescentamos o papel decisivo da Geografia, trazendo para junto da sala de aula, um tema da disciplina que se tornou assunto na atualidade, reforçando sua aprendizagem.

Enfim, por meio dessa proposta, verificou-se que essa atividade pedagógica tornou a participação dos alunos muito mais ativa, seja na pré- interação sobre o tema dos refugiados com as histórias em quadrinhos como também na produção de suas próprias histórias. Acredito que essa prática foi significativa, levando à compreensão de questões mundiais superando o senso comum dessa temática que é retratada nos noticiários, para um nível 
mais sistematizado e científico, com a finalidade de levar ao aluno um panorama mais amplo dos fatores que conduziram a ampliação desse fluxo migratório.

\section{CONSIDERAÇÕES FINAIS}

Nesta proposta, surgem situações em que os alunos seriam postos a ler e dois relatos na forma de histórias em quadrinhos, visando sensibilizá-los, antes da elaboração de suas prórpias histórias, desenvolvendo o senso criativo e crítico sobre a temática afim. Sendo uma linguagem de fácil aplicação e de baixo custo para a obtenção, elas podem ter uma boa aplicabilidade nas mais diversas situações do ensino de Geografia e em diferentes séries escolares. Acredita-se que esse tipo de atividade pedagógica poderia se transformar em uma participação mais ativa do educando, tendo em vista sua pré-interação do assunto com a história em quadrinhos.

A simples leitura de quadros animados e balões com diálogos pode exercer, junto aos educandos, uma forma de interpretação da realidade, propiciando possibilidades para a compreensão do mundo em que vivem, bem como a apreensão do conhecimento, desde o nível do senso comum para um nível mais sistematizado. Em nossa atividade, esperando como resposta dos alunos a frase: "Como eu vou fazer esse trabalho, se eu não sei desenhar ?", optou-se em buscar gratuitamente da rede mundial de computadores, um software de fácil utilização que pudesse servir de apoio ao trabalho. Sendo uma geração muito próxima das inovações no ramo da informática, tanto o bolsista/monitor como os alunos, não tiveram dificuldades em construírem suas $\mathrm{HQs}$, o que resultou em bons roteiros e expressões de personagens, que retratavam o flagelo que enfrentavam durante a busca pelo refúgio.

Assim, para que o aluno participe da construção do saber geográfico por meio das histórias em quadrinhos, o professor deve estar ciente de seu importante papel na condução dessas atividades, orientando e corrigindo a trajetória do processo, para que essa prática não se torne enfadonha e trabalhosa, mas que fortaleça na mente do aluno que além de sua aprendizagem ele estará produzindo um material que poderá ser consultado por todo o mundo e servir de auxílio para quem mais queira conhecer sobre migrações e refugiados e venha consultá-lo no site do programa Pixton, pois lá se mantén publicados.

\section{REFERÊNCIAS}

AGÊNCIA DA ONU PARA REFUGIADOS - ACNUR. Histórias de refugiados: Antônio, 16 anos, Honduras. 2011. Disponível em: <http://www.acnur.org/portugues/o-acnur/envolvase/eventos/dia-mundial-do-refugiado-2011/historias-de-refugiados/>. Acesso em: 21 de ago. 2015.

ANSELMO, M. Q. As Histórias em Quadrinhos. Petrópolis: Vozes, 1975. 
$\mathrm{BEAH}$, Ishmael. Muito Longe de Casa: memórias de um menino soldado. São Paulo: Cia de Bolso, 2014.

CAETANO, Guilherme S. Mohamed. 2015. Disponível em < https://www.pixton.com/br/comic/x1u98fqm>. Acesso em: 27 de mai. 2017.

COUTINHO, Laerte, Capitão Douglas: Guerra é Guerra. Striptiras, São Paulo, s/v, n. 4, p.12, maio 1993.

CRÉPEAU, François. Forced migration and global processes: a view from forced migration studies. Lanham; Oxford: Lexington Books, 2006.

EISNER, Will. Quadrinhos e Arte Sequencial.São Paulo: Martins Fontes, 1989.

MOREIRA, Julia B. Política em relação aos refugiados no Brasil (1947-2010). Campinas, 2012. Tese (Doutorado em Filosofia) - UNICAMP.

MOYA, Alvaro de. Shazaam! São Paulo: Perspectiva, 1980.

PIXTON COMICS INC. Pixton: A melhor maneira para criar quadrinhos. 2017. Disponível em < https://www.pixton.com/br/ >. Acesso em: 27 de mai. 2017.

${ }^{1}$ Doutorando em Geografia-UEL, Professor EBTT - IFSP/Câmpus Itapetininga/SP. irflorianoii@yahoo.com.br

${ }^{2}$ Doutora em Geografia-FCT-Unesp/P.Prudente/SP, Professora SEE-SP. dianju@yahoo.com 